\title{
UPAYA MENGIDENTIFIKASI DAN MEREDUKSI DAMPAK PANDEMI COVID 19 PADA PERKEMBANGAN SOSIAL REMAJA
}

\author{
Sri Utami ${ }^{1)}$, Anna Rufaidah ${ }^{2)}$, Afiatin Nisa ${ }^{3)}$ \\ Program Studi Bimbingan dan Konseling, FIPPS, Universitas Indraprasta PGRI
}

\begin{abstract}
Abstrak
Anak sebagai individu yang secara bertahap berkembang mengalami proses pertumbuhan dan perkembangan yang signifikan di dalam fase remaja. Perkembangan sosial remaja dapat diartikan sebagai perolehan kemampuan remaja dalam berperilaku yang sesuai dengan tuntutan sosial yang merupakan pencapaian kematangan dalam hubungan sosial, baik itu dalam tatanan keluarga, sekolah, dan masyarakat. Aspek perkembangan sosial menjadi salah satu tugas perkembangan yang dominan pada masa remaja. pandemi Covid 19 turut mempengaruhi bagaimana cara remaja dalam berinteraksi dan bersosialisasi dimana keduanya menjadi sangat terbatasi dan mengandalkan peran teknologi yang juga memiliki keterbatasan dan kekurangan. Kehidupan "new normal" yang harus dijalankan sebagai upaya meminimalisir bertambah luasnya penyebaran Covid 19 turut menjadi tantangan tersendiri bagi remaja di dalam menyiasati dan menyikapi kendala ini. Pemberian Layanan Bimbingan Kelompok menjadi salah satu alternatif cara yag dapat membantu para remaja untuk mengembangkan kemampuan dalam bersosialisasi dan berinteraksi.
\end{abstract}

Keywords: Pandemi Covid 19, Perkembangan Sosial Remaja.

\begin{abstract}
Children as individuals who gradually develop experience a significant process of growth and development in the adolescent phase. Adolescent social development can be interpreted as the acquisition of the ability of adolescents to behave in accordance with social demands, which is the achievement of maturity in social relationships, both in family, school and community structures. The aspect of social development is one of the dominant developmental tasks during adolescence. The Covid 19 pandemic has also affected how teenagers interact and socialize where both of them are very limited and rely on the role of technology which also has limitations and shortcomings. The "new normal" life that must be carried out in an effort to minimize the spread of Covid 19 is also a challenge for adolescents in dealing with this obstacle. Providing Group Guidance Services is an alternative way that can help adolescents develop skills in socializing and interacting.
\end{abstract}

Keywords: Covid 19, adolescent social development

Correspondence author: Anna Rufaidah, annarufaidah86@gmail.com, Jakarta, Indonesia (c) (1)(3)

This work is licensed under a $C C-B Y-N C$

\section{PENDAHULUAN}

"Keluarga adalah unit terkecil dalam masyarakat yang terdiri dari suami, istri, atau suami istri dan anak, atau ayah dan anaknya." (Undang-Undang Nomor 10 tahun 1992 tentang Perkembangan Penduduk dan Pembangunan Keluarga Sejahtera). Dengan berdasarkan pada pernyataan tersebut, tersirat makna bahwa kesejahteraan dalam 
keluarga secara signifikan akan turut mempengaruhi kesejahteraan masyarakat. Dalam keluarga, tiap-tiap anggota keluarga menjalankan perannya dan saling bersinergi. Dalam kaitannya dengan hal tersebut, anak juga turut memiliki peran dan mewarnai suatu kondisi keluarga. Dikutip dari wikipedia.com (https://id.wikipedia.org/wiki/Remaja), Anak (jamak: anak-anak) didefinisikan sebagai seorang lelaki atau perempuan yang belum dewasa atau belum mengalami masa pubertas. Anak sebagai individu yang secara bertahap berkembang mengalami proses pertumbuhan dan perkembangan yang signifikan di dalam fase remaja. Dalam bahasa Inggris remaja dinamai (puberty), belanda (puberteit), dan latin (pubertas) yang berarti kedewasaan yang dilandasi oleh sifat dan tanda-tanda laki-lakian dan kewanitaan, selain itu ada yang menggunakan istilah adulescentio (latin) yaitu masa muda. Dalam kamus lengkap Bahasa Indonesia (https://kbbi.web.id/remaja), remaja diartikan sebagai usia muda/pemuda atau mulai dewasa, sudah sampai umur untuk kawin.

Kurun Masa Remaja menurut pendapat ahli Havighurst (Havighurst dalam Prayitno, 2004) adalah berada pada usia 12-18 tahun dan sejalan dengan definisinya, remaja memiliki tugas perkembangan sebagai berikut sebagai berikut:

Mencapai hubungan-hubungan yang baru dan lebih matang dengan teman sebaya antar jenis kelamin yang sama dan berbeda.

Mencapai peranan sosial sebagai pria dan wanita.

Menerima kesatuan tubuh sebagaimana adanya dan menggunakannya secara efektif.

Mencapai kemerdekaan emosional terhadap orangtua dan orang dewasa lainnya.

Mencapai keadaaan dimilikinya jaminan untuk kemerdekaan ekonomi.

Memilih dan mempersiapkan diri untuk suatu pekerjaan.

Mempersiapkan diri untuk pernikahan dan kehidupan berkeluarga.

Mengembangkan keterampilan intelektual dan konsep-konsep yang perlu untuk kehidupan sebagai warga negara.

Mengembangkan hasrat dan mencapai kemampuan bertingkah laku yang dapat dipertimbangkan secara sosial.

Menguasai seperangkat nilai dan sistem etika sebagai pedoman.

Mengacu pada rincian tugas perkembangan di atas, nampak jelas berbagai aspek tugas remaja yang perlu berkembang salah satu yang cukup dominan adalah aspek perkembangan sosial yang secara rinci tergambar dari tugas remaja untuk mencapai hubungan-hubungan yang baru dan lebih matang dengan teman sebaya antar jenis kelamin yang sama dan berbeda; mencapai peranan sosial sebagai pria atau wanita; mempersiapkan diri untuk pernikahan dan kehidupan berkeluarga; serta mengembangkan hasrat dan mencapai kemampuan bertingkah laku yang dapat dipertimbangkan secara sosial.

Menurut Ahmad Susanto (2012:40), perkembangan sosial merupakan "Pencapaian kematangan dalam hubungan sosial. Dapat juga diartikan sebagai proses belajar untuk menyesuaikan diri terhadap norma-norma kelompok, moral, dan tradisi, meleburkan diri menjadi satu kesatuan dan saling berkomunikasi dan bekerja sama". Berdasarkan pemahaman tersebut, perkembangan sosial remaja dapat diartikan sebagai perolehan kemampuan remaja dalam berperilaku yang sesuai dengan tuntutan sosial yang merupakan pencapaian kematangan dalam hubungan sosial, baik itu dalam tatanan keluarga, sekolah, dan masyarakat. Dalam upaya mewujudkan hal tersebut, proses interaksi sosial sebagai kegiatan bersosialisi menjadi salah satu faktor penting yang 
turut mempengaruhi perkembangan sosial remaja. Remaja yang mampu mengembangkan aspek perkembangan sosial secara optimal akan dapat memenuhi kebutuhan dan tuntutan tugas perkembangannya sehingga kehidupan remaja dapat berjalan selaras seimbang dan memungkinkan dirinya mampu untuk memenuhi tugas perkembangan selanjutnya.

Penjelasan di atas memberikan gambaran betapa proses interaksi dan bersosialisasi memiliki peranan penting di dalam pengembangan sosial remaja. Namun sayangnya dalam 7 (tujuh) bulan terakhir, adanya pandemi Covid 19 turut mempengaruhi bagaimana cara remaja dalam berinteraksi dan bersosialisasi dimana keduanya menjadi sangat terbatasi dan mengandalkan peran teknologi yang juga memiliki keterbatasan dan kekurangan. Kehidupan "new normal" yang harus dijalankan sebagai upaya meminimalisir bertambah luasnya penyebaran Covid 19 turut menjadi tantangan tersendiri bagi remaja di dalam menyiasati dan menyikapi kendala ini. Bila hal ini berangsur-angsur terjadi dan dibiarkan tanpa adanya identifikasi dan strategi dalam menyikapinya maka perkembangan sosial remaja dapat mengalami hambatan yang memiliki dampak lebih serius di masa ke depannya.

Bimbingan dan Konseling sebagai pelayanan yang bekerja dalam setting pendidikan dan setting luar pendidikan (masyarakat) yaitu termasuk keluarga (kode etik IKI, 2016), dapat turut mengambil peran dalam ranah Pemberdayaan Kesejahteraan Keluarga (PKK) dengan memberikan pelayanan BK berupa layanan Bimbingan Kelompok (disingkat BKp) guna mengupayakan kendala yang dialami remaja dalam perkembangan sosialnya. Layanan Bimbingan Kelompok merupakan salah satu jenis layanan BK yang memiliki kekhasan yaitu dengan pemanfaaatan dinamika kelompok. Layanan Bimbingan Kelompok merupakan layanan BK yang berfokus pada pembahasan topik-topik tertentu yang bersifat umum dan mengandung permasalahan actual (hangat) dan menjadi perhatian peserta melalui dinamika kelompok yang intensif, pembahasan topik-topik itu mendorong pengemabangn perasaan, pikiran, persepsi, wawasan, dan sikap yang menunjang diwujudkannya tingkah laku yang lebih efektif dan bertanggung jawab. Dalam hal ini kemampuan berkomunikasi verbal maupun nonverbal ditingkatkan (Prayitno,2012: 151).

Menurut Folastri dan Rangka (2018) bimbingan kelompok memiliki beberapa asas-asas dasar dalam kegiatan pelayanan konseling kelompok yang wajib diterapkan dan sebagai dasar pelaksanaan layanan bimbingan kelompok bahwa asas kerahasiaan, kesukarelaan, dan keputusan dijalankan oleh diri klien sendiri tanpa dan paksaan dari orang lain. Asas-asas layanan bimbingan kelompok adalah sebagai berikut:

Asas kerahasian

Asas kerahasiaan adalah segala sesuatu yang dibahas dan muncul dalam kegiatan kelompok hendak menjadi "rahasia kelompok" yang hanya boleh diketahui oleh anggota kelompok dan tidak boleh disebarluaskan keluar kelompok. Asas kerahasiaan sangat penting dalam layanan bimbingan kelompok dikarenakan pokok bahasan adalah masalah pribadi yang dialami anggota kelompok.

Asas kesukarelaan

Asas kesukarelan adalah asas yang mengharuskan semua anggota kelompok untuk berperan aktif diri mereka masing-masing untuk mencapai tujuan layanan. Dan kesukarelaan anggota kelompok dimulai sejak awal rancana pembentukan kelompok oleh konselor atau pemimpin kelompok. kesukarelaan terus-menerus harus bina melalui upaya konselor atau pemimpin kelompok dalam mengembangkan dan menghasilkan kelompok yang efekif. 
Asas keterbukaan

Asas keterbukaan adalah asas yang mengharuskan anggota kelompok aktif dan terbuka menampilkan diri tanpa rasa takut, malu atau pun ragu. Dinamika kelompok yang semakin tinggi, berisi, bervariasi menciptakan konseling kelompok semakin kaya dan terasa sehingga dimungkinkan memperoleh hal-hal yang berharga dari layanan bimbingan kelompok.

Asas kekinian

Asas kekinian adalah masalah yang dibahas dalam bimbingan kelompok berisi aktual atau sedang dialami oleh anggota kelompok, anggota kelompok diminta mengemukakan hal-hal yang terjadi dan dirasakan saat ini. Hal-hal atau pengalaman yang telah dikemukakan kemudian dianalisis untuk mencari jalan keluar dari permaslaahan yang dirasakan saat ini dan hal-hal yang mungkin terjadi dimasa akan datang direncanakan sesuai dengan kondisi yang ada saat ini.

Asas kenormatifan

Asas kenormatifan adalah dalam pelaksanaan layanan bimbingan kelompok dilakukan dengan cara-cara yang baik, bertata-krama yang baik dan tidak melanggar norma hukum, norma agama, dan norma kesusilaan.

Asas keahlian

Asas keahlian adalah layanan bimbingan kelompok dipimpin oleh seorang yang ahli dalam bidang layanan bimbingan kelompok (konselor) dan konselor pun memperlihatkan bagaimana dalam mengelola kegiaan kelompok untuk mengembangkan proses dan isi pembahasan secara keseluruan.

Menurut Prayitno dan Afdal, dkk. (2017: 90) layanan bimbingan konseling kelompok memiliki dua tujuan yang dicapai dalam pelayanan bimbingan kelompok, dua tujuan pelayanan dalam bimbingan kelompok adalah sebagai berikut :

Layanan bimbingan kelompok berguna untuk pengembangan pribadi perserta didik dengan memanfaatkan potensi yang dimiliki perserta didik untuk membahas permasalan dengan memanfaatkan dinamika kelompok

Pembahasan masalah atau topik-topik masalah dengan secara umum dan mendalam agar manfaatnya terasa bagi setiap anggota kelompok

Berdasarkan uraian pendahualuan di atas, pemberian Layanan Bimbingan Kelompok menjadi sebuah treatment dan solusi yang dapat diberikan kepada para remaja pada lingkungan mitra guna memungkinkan peserta layanan sebagai Anggota Kelompok (AK) tidak hanya mendapatkan penguatan WPKNS (Wawasan, Pengetahuan, Keterampilan, Nilai, dan Sikap) terkait dengan topik yang dibahas tetapi juga sekaligus membantu AK (anggota kelompok) memiliki kemampuan dalam bersosialisasi dan berinteraksi.

\section{METODE PELAKSANAAN}

Kegiatan pengabdian masyarakat ini dilakukan pada remaja PKK RW 02 yang berlokasi di Gang Swadaya 1 RT 006 RW 002 Jatimurni Pondok Melati Kota Bekasi. PKK RW 02 yang berlokasi di Gang Swadaya 1 RT 006 RW 002 Jatimurni Pondok Melati Kota Bekasi, merupakan lembaga yang secara konsisten untuk terus mengupayakan peningkatan kesejahteraan keluarga melalui berbagai aspek dan lintas profesi. Pada bulan September, tim Abdimas melakukan kunjungan ke lokasi kegiatan sebagai bagian dari tahap pelaksanaan sehingga tim dapat mengetahui kondisi lapangan 
yang akan menjadi tempat pelaksanaan kegiatan. Tinjauan lokasi dilakukan untuk menjalin komunikasi interaktif terhadap mitra kegiatan. Melakukan observasi untuk mendapat informasi yang berhubungan dengan pelaksanaan kegiatan PKM. Data yang dimaksud diantaranya adalah profil PKK RW 02 sebagai mitra kegiatan PKM, sarana dan prasarana yang mendukung kegiatan PKM, dan kondisi remaja di Lingkungan PKK RW 02 dalam melaksanakan kehidupan efektif sehari-hari. Studi kepustakaan dilakukan dengan mencari referensi untuk kebutuhan teoritis tentang kegiatan PKM ini. Studi kepustakaan dilakukan dengan mencari buku-buku yang sesuai kebutuhan kegiatan pengabdian masyarakat, browsing melalui search engine, dan memanfaatkan berbagai buku pribadi yang dimiliki tim Abdimas. Melakukan analisis terhadap kebutuhan-kebutuhan yang dapat menunjang penerapan kegiatan PKM. Beberapa aspek analisis kebutuhan diantaranya lokasi, perlengkapan, peralatan penunjang, teknologi informasi, serta ketersediaan personil yang ada di PKK RW 02.

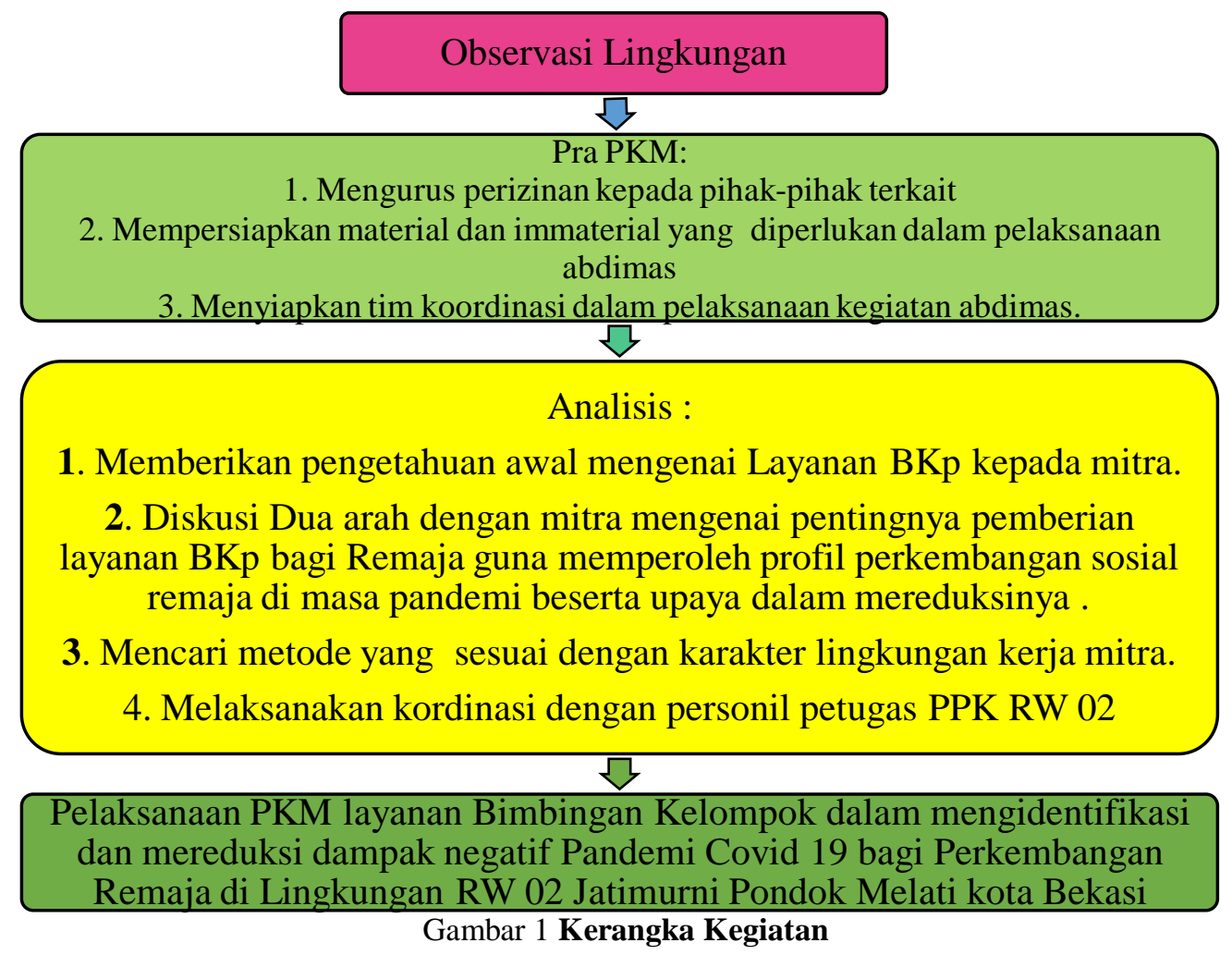

Pada saat pelaksanaan kegiatan, tim abdimas menggunakan metode penyampaian materi jarak jauh dengan memanfaatkan media audio visual yaitu melalui Video Call Whatsapp. Identifikasi dan Upaya Mereduksi dampak negatif Pandemi Covid 19 Bagi Perkembangan remaja diperoleh melalui pemanfaatan dinamika kelompok dalam pemberian layanan Bimbingan Kelompok. Pemberian Layanan Bimbingan Kelompok memungkinkan Anggota Kelompok (Peserta Layanan) untuk ber-BMB3 dalam menyikapi hambatan dan tantangan yang ada dalam perkembangan sosialnya sehingga melalui dinamika kelompok dikaji bagaimana cara mengatasinya. 


\section{HASIL DAN PEMBAHASAN}

Kegiatan abdimas yang dilakukan oleh tim dalam pelaksanaannya yaitu PKM Layanan Bimbingan Kelompok (BKp) untuk Mengidentifikasi dan Mereduksi Dampak Pandemi Covid 19 Pada Perkembangan Remaja di Lingkungan PKK RW 02 Jatimurni Pondok Melati Kota Bekasi. Dimana kegiatan pengabdian kepada masyarakat ini berlangsung selama 2 hari. Pemberian Layanan Bimbingan Kelompok menjadi upaya yang diberikan guna mengembangkan kemampuan bersosialisasi dan berinteraksi serta menyesuaikan diri dalam kehidupan "new normal" selama masa pandemic covid 19 dan mereduksi dampak-dampak negatif dalam perkembangan kehidupan sosial remaja. Mengangkat isu perkembangan sosial remaja selama 7 bulan terakhir masa pandemi covid 19 di Indonesia sebagai aspek yang perlu disadari turut memberikan dampak negatif bagi perkembangan sosial remaja dan hal ini menjadi penting untuk diperhatikan.

Bentuk perhatian yang ditawarkan adalah dengan memberikan Layanan BKp Guna mengidentifikasi dan melakukan upaya mereduksi dampaknya

1. Penyelenggaraan Layanan Bimbingan Kelompok (BKp) yang memungkinkan Anggota Kelompok (AK) bertukar pikiran, pendapat, perasaan, ide dan tanggapan tentang dampak covid 19 bagi kehidupannya, selain bertukar pikiran, pendapat, dan perasaan, AK didorong untuk memiliki rumusan positif dalam menyikapi berbagai kendala yang dihadapi dalam mengembangkan kehidupan sosialnya hingga mampu melakukan tindakan yang berorientasi pada upaya mereduksi berbagai hambatan yang dialaminya atau potensi akan adanya dampak panjang yang lebih serius.Menyebarkan angket untuk memperoleh informasi akan respons peserta dalam mengikuti kegiatan, manfaat yang dirasakan setelah mengikuti kegiatan serta rencana (komitmen) setelah mendapatkan keterampilan yang diperoleh dari kegiatan.

2. Melakukan laiseg (Penilaian Segera) untuk memperoleh informasi tentang tingkat antusias peserta dalam mengikuti kegiatan, manfaat yang dirasakan setelah mengikuti kegiatan serta rencana setelah mendapatkan keterampilan yang diperoleh dari kegiatan.

\section{Tahapan Layanan Bimbingan Kelompok}

Adapun tahapan-tahapan yang dilakukan dalam layanan bimbingan kelompok adalah sebagai berikut:

1. Tahap Pembentukan, pada tahap ini Tim Abdimas yang bertugas sebagai Pemimpin Kelompok (PK) melakukan penstrukturan dengan mengucapkan salam, mengungkapkan rasa syukur dan senang atas kehadiran peserta dalam kegiatan yang akan dilakukan, memperkenalkan diri, menjelaskan maksud dan tujuan dari kegiatan yang diadakan, menjelaskan teknis kegiatan termasuk didalmnya adalah upaya mewujudkan asas kesukarelaan, keterbukaan, kenormatifan, dan kerahasiaan. Dalam tahapan ini PK juga mempersilakan Anggota Kelompok (AK) untuk memperkenalkan diri secara bergantian.

2. Tahap Peralihan, pada tahap ini PK melakukan konfirmasi kepada AK paham tidaknya atas penjelasan yang PK berikan dan memberikan kesempatan kepada AK untuk bertanya bilamana masih ada hal yang belum dipahami dari penjelasan yang PK berikan. Setelah itu PK meminta kesepakatan untuk masuk dalam kegiatan inti.

3. Tahap Kegiatan, pada tahap ini PK menyampaikan topik yang perlu dibahas dan memberikan berbagai fenomena yang terjadi sebagai dampak dari pandemi korona 
setelah dirasakan cukup, PK memberikan kesempatan setiap AK memberikan respons berupa isi pikiran (pendapat, tanggapan, ide, pengalaman) maupun isi perasaannya. Selama kegiatan berlangsung, PK berupaya mengarahkan pembahasan tidak bias pada topik yang lain diluar kehidupan sosial remaja di masa pandemi dan berusaha untuk mengembangkan dinamika kelompok melalui pengembangan BMB-3 pada setiap diri AK.

4. Tahap Penutup, tahap ini merupakan kegiatan akhir dari seluruh rangkaian kegiatan dimana pada tahap ini PK memberikan rangkuman dari hasil pembahasan yang telah dilakukan bersama, kemudian PK memberikan peneguhan hasrat. Terakhir, PK meminta AK memberikan pesan dan kesan setelah mengikuti layanan BKp sebagai bentuk evaluasi layanan (Penilaian Segera/laiseg).

\section{Perubahan WPKNS pada peserta layanana Bimbingan Kelompok}

Bertambahnya wawasan, pengetahuan, keterampilan, nilai, dan sikap (WPKNS) yang dimiliki para remaja dalam memahami pentingnya optimalisasi perkembangan sosial di masa pandemi dengan menemukan cara-cara/strategi untuk tetap dapat tetap mengoptimalkan aktivitas berinteraksi, berkomunikasi, dan bersosialisasi secara jarak jauh yang diperoleh melalui proses Berpikir, Merasa, Bersikap, Bertindak, dan Bertanggungjawab atas perkembangan sosial dirinya dan orang lain di sekitarnya. Hal ini dibuktikan dengan munculnya beberapa indikator penilaian proses selama layanan BKp berlangsung, diantaranya sebagai berikut:

1. Adanya respon positif yang ditunjukkan dengan kesediaan remaja di lingkungan PKK RW 02 Jatimurni Pondok Melati Kota Bekasi dalam mengikuti kegiatan BKp sampai dengan selesai, adanya keterlibatan aktif remaja sebagai Anggota Kelompok (AK) di dalam kegiatan BKp ini dimana tiap-tiap AK memberikan pendapat, tanggapan, pengalaman, hingga permasalahan yang dialaminya untuk dibagikan dan direspons oleh AK lainnya.

2. Adanya pemikiran kearah yang positif dengan terlihatnya penambahan wawasan, pengetahuan, keterampilan, nilai, dan sikap dalam mengolah informasi yang diterima dari AK lainnya (bertukar pikiran, Perasaan, dan Pengalaman).

3. Adanya keterbukaan mengenai pengalaman dan permasalahan yang disampaikan oleh para AK berkaitan dengan kondisi yang terjadi pada interaksi sosialnya selama pandemi.

4. Adanya ungkapan rasa senang atas adanya kegiatan BKp yang baru pertama kali diikuti dan adanya kesan kognitif dimana AK menjadi lebih tahu dan lebih perhatian terhadap perkembangan sosialnya di masa pandemi ini.

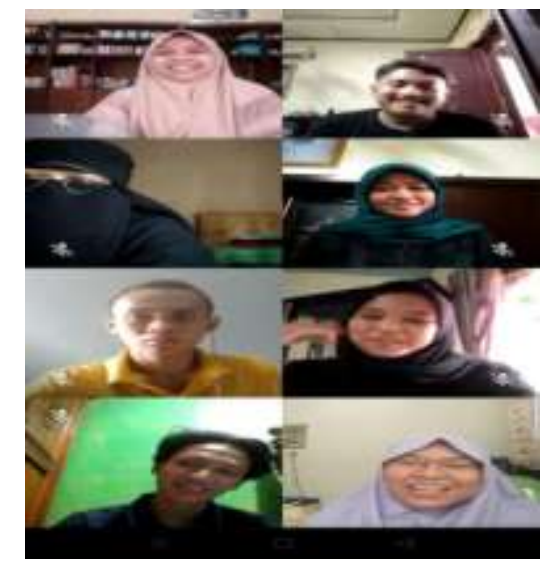

Gambar 2 Pelaksanaan BKp melalui Video Call Whatsapp 


\section{SIMPULAN}

Berdasarkan hasil kegiatan pengabdian kepada masyarakat yang dilakukan dapat disimpulkan bahwa PKM Layanan Bimbingan Kelompok (BKp) untuk Mengidentifikasi dan Mereduksi Dampak Pandemi Covid 19 Pada Perkembangan Remaja di Lingkungan PKK RW 02 Jatimurni Pondok Melati Kota Bekasi telah turut membantu meningkatkan pemahaman dan keterampilan dalam mengembangkan kehidupan sosial remaja di lingkungan PKK RW 02 Jatimurni Pondok Melati Kota Bekasi yaitu melalui pembahasan topik dalam layanan BKp yang mendorong remaja (Anggota Kelompok) menjadi lebih ber-BMB3 (Berpikir, Merasa, Bersikap, Bertindak, dan Bertanggung Jawab), yaitu menjadi berpikir secara lebih mendalam, mengidentifikasi dan menginterpretasikan isi perasaan, mengambil sikap dan tindakan yang tepat serta menjadi lebih bertanggung jawab atas optimalisasi perkembangan sosial dirinya yang penuh tantangan dan hambatan selama masa pandemi ini.

\section{DAFTAR PUSTAKA}

BKKBN. (1992) Undang-Undang Republik Indonesia Nomor 10 Tahun 1992. Tentang Perkembangan Kependudukan dan Pembangunan Keluarga Sejahtera. Badan Koordinasi Keluarga Berencana Nasional.PP IKI. 2016. Spektrum Kinerja dan Kode Etik Profesional Konselor Indonesia.

Prayitno. 2014. Pembelajaran melalui pelayanan BK di satuan Pendidikan. Yogyakarta: Paramitra Publishing 2012. Jenis Layanan dan Kegiatan Pendukung Konseling. Padang: UNP

Prayitno, Erman Amti. 2004. Dasar-Dasar Bimbingan dan Konseling. Yogyakarta: Paramitra Publishing

Rumini, Sri dan Siti Sundari. 2004. Perkembangan Anak dan Remaja. Jakarta: PT Rineka Cipta

Susanto, Ahmad. 2012. Perkembangan Anak Usia Dini :Pengantar dalam Berbagai Aspeknya. Jakarta: Kencana Prenada Media Group

Wikipedia, 2020 (https://id.wikipedia.org/wiki/Remaja)

Kemdikbud, 2021 (https://kbbi.web.id/remaja) 